\section{IN VITRO CYTOTOXIC EVALUATION AND APOPTOTIC EFFECTS OF DILLAPIOLE ON HUMAN NASAL SQUAMOUS CELL CARCINOMA}

\author{
Nur Batrisyia Ruslana, Indah Mohd Amina*, Narimah Abdul Hamid \\ Hasani $^{b}$, Vivi Noryati Ahmada, Farizan Arisc, Khor Goot Heaha
}

aCentre of Preclinical Sciences Studies, Faculty of Dentistry, Universiti Teknologi MARA (UiTM), Sungai Buloh, Selangor, Malaysia bDepartment of Biochemistry and Molecular Medicine, Faculty of Medicine, Universiti Teknologi MARA (UiTM), Sungai Buloh, Selangor, Malaysia

'School of Biology, Faculty of Applied Sciences, Universiti Teknologi MARA (UiTM) Shah Alam, Selangor, Malaysia
Article history

Received

24 May 2021

Received in revised form

20 July 2021

Accepted

4 August 2021

Published online

20 August 2021

*Corresponding author indahma@uitm.edu.my

\section{Graphical abstract}

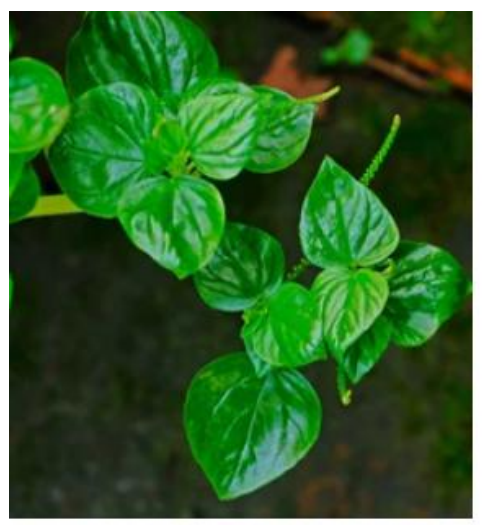

Peperomia Pellucida

\begin{abstract}
Dillapiole is one of the major compounds in Peperomia pellucida. Dillapiole exerts cytotoxicity effect on several cancer cells such as breast and colon with a minimal effect on normal cells. However, its effect on cancers in head and neck region remains ambiguous. Therefore, in the current study, the cytotoxicity effect of dillapiole on human nasal squamous cell carcinoma, RPMI 2650 and the underlying mechanism were investigated. Normal human gingival fibroblast, HGnF cells was used as comparison. Cisplatin and untreated cells were used as positive and negative controls, respectively. Cell cytotoxicity was determined using WST-1 assay; and validated by trypan blue exclusion assays. Cell death mechanism was determined using Annexin VFITC detection kit and analyzed by flow cytometer. The cytotoxic effect of dillapiole on RPMI 2650 cells was shown significantly increased with the increasing amount of dillapiole from $25.93 \pm 6.39 \%$ to $83.87 \pm 8.43 \%(p<0.05$, $\mathrm{n}=3$ ) with the respective $\mathrm{I} \mathrm{C}_{50}$ and $\mathrm{I} \mathrm{C}_{75}$ of $46 \mu \mathrm{M}$ and $\mathrm{I} 25 \mu \mathrm{M}$. None of both $\mathrm{IC}_{50}$ and $\mathrm{IC}_{75}$ were obtained for HGnF cells up to $150 \mu \mathrm{M}$. Loss of normal shape, cytoplasm shrinkage and reduction in cell volume were detected in RPMI 2650 cells after dillapiole treatment at respective $I_{50}(46 \mu \mathrm{M})$ and $I_{75}(125$ $\mu M)$, indicating apoptosis. These findings indicate that dillapiole cytotoxicity effect is more selective towards RPMI 2650 compared to HGnF cells and the mechanism of death was through the induction of apoptosis.
\end{abstract}

Keywords: RPMI 2650 cells, dillapiole, cytotoxicity, apoptosis, Caspase 8 and $\mathrm{BCL} 2$ proteins

\begin{abstract}
Abstrak
Dillapiole adalah salah satu sebatian utama dalam Peperomia pellucida. Dillapiole memberikan kesan sitotoksisiti pada beberapa sel kanser seperti payudara dan usus besar dengan kesan minimum pada sel normal. Walau bagaimanapun, kesannya terhadap kanser di kawasan kepala dan leher masih tidak jelas. Oleh itu, dalam kajian semasa, kesan sitotoksisiti dillapiole pada karsinoma sel skuamosa hidung manusia, RPMI 2650 dan mekanisme penyebab berlakunya kanser diselidiki. Sel normal fibroblast gingival manusia, iaitu sel HGnF digunakan sebagai perbandingan. Sel RPMI 2650 yang dirawat dengan cisplatin dan tidak dirawat masing-masing digunakan sebagai
\end{abstract}


kawalan kajian positif dan negatif. Sitotoksisiti sel ditentukan dengan
menggunakan Ujian WST-1; dan disahkan oleh ujian pengecualian trypan
blue. Mekanisme kematian sel ditentukan menggunakan kit pengesanan
Annexin V-FITC dan dianalisis dengan sitometer aliran. Kesan sitotoksik
dillapiole pada sel RPMI 2650 ditunjukkan meningkat dengan ketara dengan
peningkatan jumlah dillapiole dari $25,93 \pm 6,39 \%$ menjadi $83,87 \pm 8,43 \%$ (p
$<0,05, \mathrm{n}=3$ ) dengan IC 50 dan IC75 masing-masing $46 \mu \mathrm{M}$ dan $125 \mu \mathrm{M}$. Tidak
satu pun dari kedua IC 50 dan IC75 diperoleh untuk sel HGnF hingga $150 \mu \mathrm{M}$.
Kehilangan bentuk normal, penyusutan sitoplasma dan pengurangan jumlah
sel dikesan pada sel RPMI 2650 setelah perlakuan dillapiole pada masing-
masing IC50 ( $46 \mu \mathrm{M}$ ) dan IC75 ( $125 \mu M$ ), menunjukkan berlakunya mekanisme
apoptosis. Penemuan ini menunjukkan bahawa kesan sitotoksisiti dillapiole
lebih selektif terhadap RPMI 2650 berbanding dengan sel HGnF. Mekanisme
kematian sel didapati menunjukkan ianya berlaku melalui apoptosis.
Kata kunci: RPMI 2650 cells, dillapiole, sitotoksisiti WST-1 dan apoptosis
(C) 2021 Penerbit UTM Press. All rights reserved

\subsection{INTRODUCTION}

The use of natural products and their derivatives as one of the preventions and alternative medicine to fight diseases and other medical conditions including cancer has been widely used since ancient times. In the context of cancer treatment, anticancer drug paclitaxel that was used to treat small and non-small cell lung cancer and advanced breast cancer was isolated from Taxus spp. or English yew [1]. Vinblastine and vincristine, are chemotherapy agents for lymphoma, breast and lung cancer as well as leukemia come from the Madagascar periwinkle, Catharanthus roseus (L.) [2] and Combretum caffrum is a South African tree that contains combrestatins, an anticancer drug that works against leukemia, colon and lung cancer [3].

Peperomia pellucida or commonly known as "Sirih Cina" or "Ketumpangan Air" in Malay comes from a family of Piperaceae [4 \& 6]. It can be found extensively in Malaysia and is known to heal gout, fever, headache, fatigue, skin diseases along with breast cancer [5]. Other studies also reported that this plant poses the bioactivities such as a cytotoxic, anti-diabetic, anti-oxidant, anti-microbial and ntihypercholesterolemia [6]. The extracted oil of this plant is reported to contain dillapiole (55.3\%), caryophyllene (14.3\%) and carotol (8.1\%) which are the major compounds found in Peperomia pellucida [7].

In this study, cytotoxicity effect of dillapiole on human nasal squamous cell carcinoma, RPMI 2650 cells were investigated through WST-1 assay. The cytotoxicity results were further validated with trypan blue exclusion assay as well as microscopic imaging using the obtained $\mathrm{IC}_{50}$ and $\mathrm{IC}_{75}$ as a reference. The inhibition mechanism of dillapiole against RPMI 2650 was determined by apoptosis assay using Annexin $\mathrm{V}$ FITC detection kit and was analyzed using a flow cytometer.

Cell death may take place in several mechanisms, namely necrosis, apoptosis, autophagy, and pyroptosis [8]. Apoptosis, a type of programmed cell death can be activated by several conditions both pathologically and physiologically [9]. Morphologically, apoptosis can be differentiated by condensation and fragmentation of it's nuclear as well as cell shrinkage and blebbing of membrane [9]. In the present studies, the loss of membrane integrity of the cells was detected by Annexin $\vee$ that interacts with phosphatidylserine that was being exposed to the cell surface.

\subsection{METHODOLOGY}

\subsection{Cell Culture}

Human nasal squamous cell carcinoma (ATCC, RPMI 2650) was purchased from the American Type Culture Collection and cultured in Eagle's Minimum Essential Medium (EMEM; ATCC, USA) supplemented with 10\% fetal bovine serum (FBS; Gibco, USA), 100 units $/ \mathrm{mL}$ penicillin and $100 \mathrm{ug} / \mathrm{mL}$ streptomycin (PenStrep; Gibco, USA). Normal human gingival fibroblast cell line (ATCC, HGnF), was cultured in complete fibroblast media supplemented with $2 \%$ FBS, $1 \%$ fibroblast growth supplement and $1 \%$ antibiotics consisting of $10,000 \mathrm{IU}$ penicillin $10 \mathrm{mg} / \mathrm{mL}$ streptomycin $(10,000 \mathrm{U} / \mathrm{ml})$. Both cells were cultured in T75 flasks to approximately $70 \%$ confluency and incubated at $37^{\circ} \mathrm{C}$ under a humidified atmosphere containing $5 \% \mathrm{CO}_{2}$.

\subsection{Preparation of Compound}

Dillapiole (Extrasynthese, France) and cisplatin (Sigma-Aldrich, USA) were dissolved in dimethyl sulfoxide (DMSO) at $50 \mathrm{mM}$ as the main stock solution. The final working solutions of dillapiole and cisplatin were diluted with culture media so that the final concentration of DMSO in cell culture is $<0.1 \%$. The DMSO percentage is indicated as nontoxic to cells. Cisplatin was used as a positive control. Serial dilution 
of both dillapiole and cisplatin were prepared accordingly.

\subsection{Cell Proliferation WST-1 Assay}

A total of $1 \times 10^{4}$ cells were seeded into each well of a 96-well microplate as monolayer in $100 \mu \mathrm{L}$ complete culture media and incubated in humidified atmosphere of $5 \% \mathrm{CO}_{2}$ at $37^{\circ} \mathrm{C}$ for 24 hours before treated separately with dillapiole and cisplatin at different final concentrations of $0,10 \mu \mathrm{M}, 25 \mu \mathrm{M}, 50$ $\mu \mathrm{M}, 75 \mu \mathrm{M}, 100 \mu \mathrm{M}, 125 \mu \mathrm{M}$ and $150 \mu \mathrm{M}$. Each treatment was done in triplicates and repeated three times. Cisplatin and untreated cells were used as positive and negative controls, respectively. After 72 hours of treatment, half of the media were removed and replaced with fresh media. A total of $10 \mu \mathrm{L}$ of WST-1 reagent was added into each well and incubated again for 3 hours. The microplate was placed on a shaker for 1 minute and absorbance was measured at a wavelength of $420 \mathrm{~nm}$ and with a reference wavelength of $620 \mathrm{~nm}$ using a TECAN microplate reader.

\subsection{Trypan Blue Exclusion Assay and Microscopic Imaging}

Cells were seeded at $1 \times 10^{5}$ in a 12 -well plate and treated with a concentration of $46 \mu \mathrm{M}$ (IC 50 dillapiole), $125 \mu \mathrm{M}$ ( $\left(\mathrm{C}_{75}\right.$ dillapiole), $8 \mu \mathrm{M}$ (IC $\mathrm{C}_{50}$ cisplatin) and untreated cells separately for 72 hours and incubated in $5 \% \mathrm{CO}_{2}$ at $37^{\circ} \mathrm{C}$. The cells were observed under an inverted light microscope at 10X magnification to view the cell morphology. Then, cells were washed with PBS and replaced with a new complete culture medium and trypsinized. The cells suspension was centrifuged at $1700 \mathrm{rpm}$ for 5 minutes and the supernatant of each treated and untreated cell were removed. The cells pellet was resuspended in $1 \mathrm{~mL}$ of culture medium. Ten $\mu \mathrm{L}$ of the content was mixed with $10 \mu \mathrm{L}$ of trypan blue dye solution. Cell counting was done by using Countess automated cell counter and recorded.

\subsection{Apoptosis Assay}

RPMI 2650 cells were seeded in a 12-well plate at concentration of $1 \times 10^{5}$ per well and treated with concentration $46 \mu \mathrm{M}$ (IC $\mathrm{C}_{50}$ dillapiole), $125 \mu \mathrm{M}\left(\mathrm{IC}_{75}\right.$ dillapiole), $8 \mu \mathrm{M}$ (IC $\mathrm{C}_{50}$ cisplatin) for 72 hours. The negative control are the untreated cells. Later the cells were washed twice with cold PBS and centrifuged at $1700 \mathrm{rpm}$ for 5 minutes at $37^{\circ} \mathrm{C}$, then resuspend in 1 Xbinding buffer and centrifuged again. The cells were transferred to a sterile flow cytometer tube. Five $\mu \mathrm{L}$ Annexin V-FITC and $10 \mu \mathrm{L}$ of propidium iodide were added and then incubated in the dark at room temperature for 30 minutes. The cells were analyzed by flow cytometer BD FACSCanto II Flow Cytometry (BD Bioscience, USA).

\subsection{RESULTS AND DISCUSSION}

\subsection{Cytotoxic Effect of Dillapiole and Microscopic Analysis}

From the Figure 1, dillapiole is more cytotoxic to RPMI 2650 cells with $25.93 \pm 6.39 \%$ to $83.87 \pm 8.43 \%$ ( $p<0.05$, $\mathrm{n}=3$ ) inhibition compared to HGnF cells with slight inhibition of $6.76 \pm 1.81 \%$ to $30.38 \pm 4.62 \%(p<0.05, n=3)$ at all concentrations used. Respective $\mathrm{IC}_{50}$ and $\mathrm{IC}_{75}$ concentrations of $46 \mu \mathrm{M}$ and $125 \mu \mathrm{M}$ were obtained for RPMI 2560 cells but none for HGnF cells. All reading is significant as compared to untreated cells at $\mathrm{p}<0.05$.

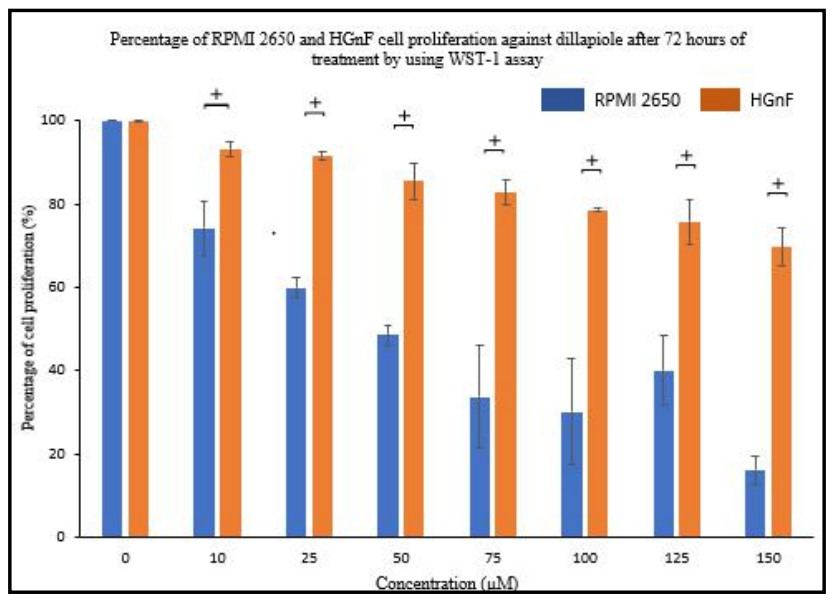

Figure 1 Effects of dillapiole on the proliferation of human nasal epithelial cancer cells, RPMI 2650 compared to normal human gingival fibroblast cells, HGnF

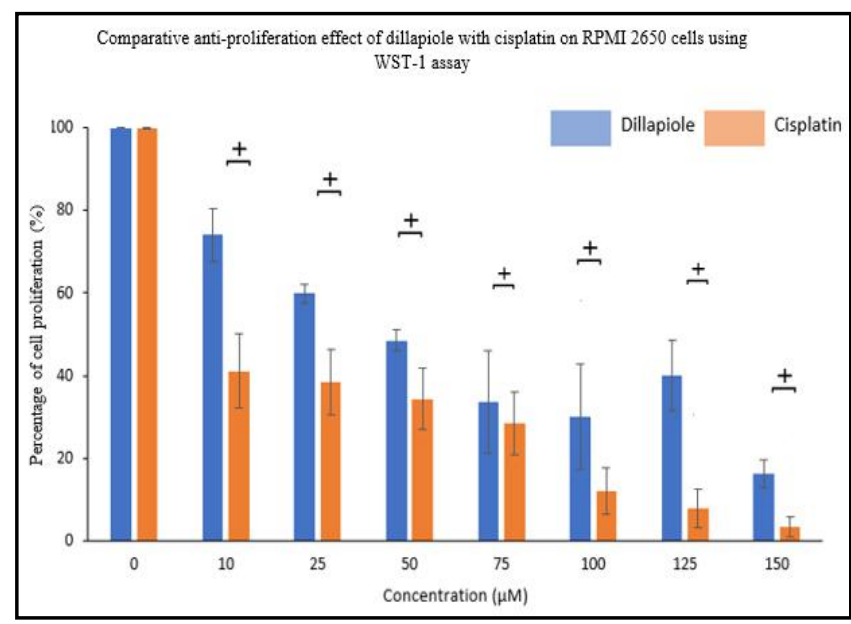

Figure 2 Comparative effects of dillapiole and cisplatin on the proliferation of human nasal epithelial cancer cells, RPMI 2650.

Figure 2 shows, both dillapiole and cisplatin were cytotoxic to RPMI 2650 cells with inhibition of $25.93 \pm 6.39 \%$ to $83.87 \pm 8.43 \%(p<0.05, n=3)$ and $58.91 \pm 8.9 \%$ to $96.64 \pm 2.3 \%(p<0.05, n=3)$, respectively at all concentration used. Both 
inhibitions were dose dependent. Dillapiole $\mathrm{IC}_{50}$ and $\mathrm{IC}_{75}$ concentrations were $46 \mu \mathrm{M}$ and $125 \mu \mathrm{M}$, respectively while cisplatin $I_{50}$ concentration was obtained at $8 \mu \mathrm{M}$. All reading is significant as compared to untreated cells at $p<0.05$.

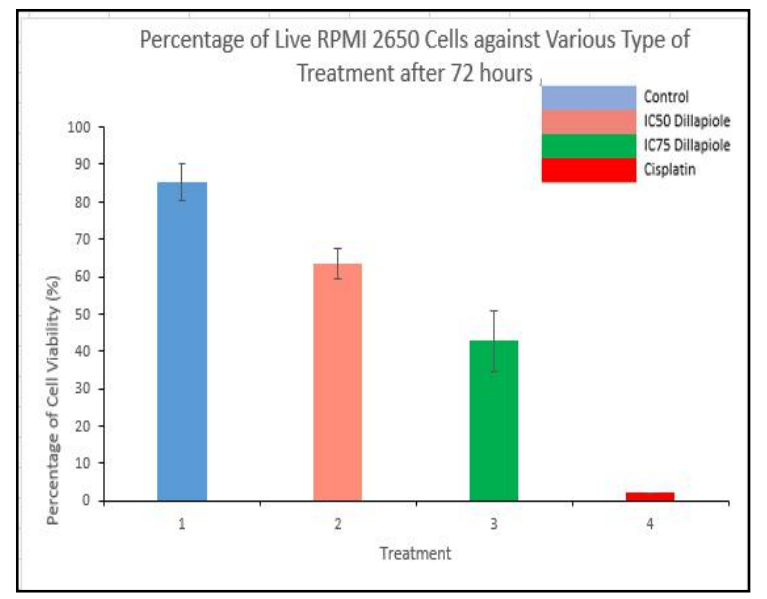

Figure 3 Percentage RPMI 2650 cells viability against various types of treatments after 72 hours

After 72 hours, the effects of dillapiole and cisplatin on viability of RPMI 2650 cells were measured by trypan blue exclusion assay. Figure 3 shows that untreated RPMI 2650 cells produced a large number of live cells, whereas cisplatin-treated cells produced a large number of dead cells. Treatment with $46 \mathrm{M}$ dillapiole resulted in a considerable reduction in cell population, whereas treatment with $125 \mathrm{M}$ dillapiole resulted in a large degree of cell mortality and a reduction in cell viability.
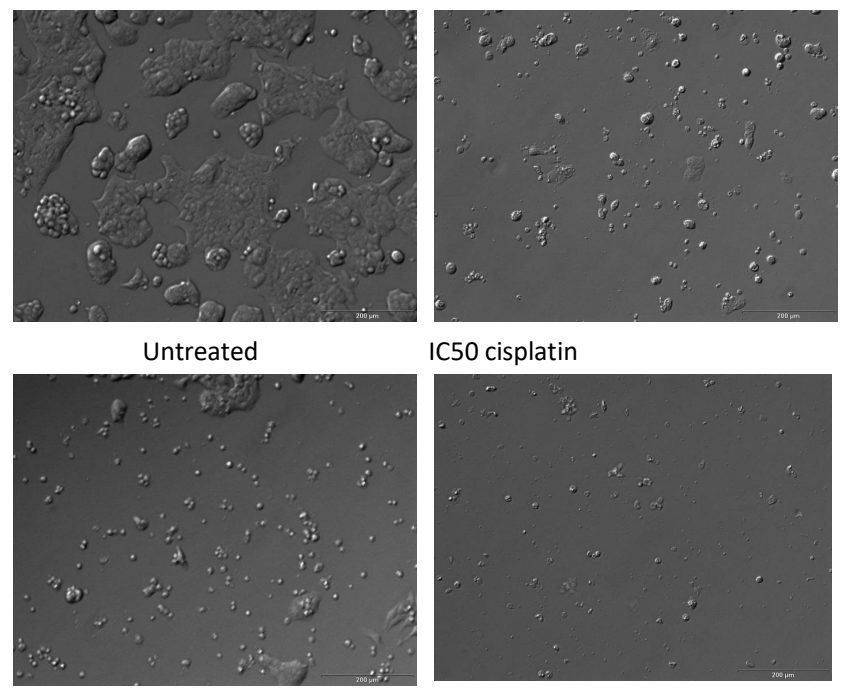

IC50 cisplatin

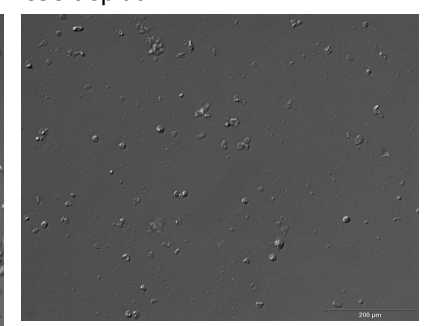

IC50 dillapiole

IC75 dillapiole

Figure 4 Microscopic views on the representative image of dillapiole and cisplatin treatment on the proliferation of human nasal epithelial cancer cells, RPMI 2650
The microscopic views on the effects of dillapiole and cisplatin on RPMI 2650 cells were observed using 40x inverted light microscope after treatment for 72 hours (Figure 4). The cells treated with both cisplatin and dillapiole had lost of their normal shape with the cytoplasm were shown shrinkage. Cells were apparently forming a membrane bound apoptotic bodies. The significant reduction of cell volume was clearly observed in both dillapiole treated cells $\left(\mathrm{IC}_{50}=\right.$ $46 \mu \mathrm{M}$ and $\left.\mathrm{IC}_{75}=125 \mu \mathrm{M}\right)$ with the highest low viability was shown at $\mathrm{IC}_{75}$ concentration.

The capability of killing cancer cells by cytotoxic agents is an important aspect in the treatment of cancer. In this study, dillapiole was found to have cytotoxic and apoptotic effects towards human nasal squamous carcinoma cells, RPMI 2650 cells. Dillapiole is a primary compound in plants from Piperaceace family [10] was found to have cytotoxic effects towards MDA-MB-231, breast cancer cell, SKMEL-28, skin cancer melanoma cells and SBCL2 cutaneous melanoma cells [11]. The trypan blue dye exclusion assay is based on the principle on dead cells absorb trypan blue into its cytoplasm, live cells unstained [12].

The selective cytotoxicity of dillapiole on RPMI 2650 cells might be due to the presence of 1,3benzodioxole system in its molecular structure. Benzodioxoles, found naturally occurring in phytochemicals as well as in anticancer agents such as podophyllotoxin, steganacin and combretastatin A-2 exhibited good bioavailability and selective cytotoxicity effects [13]. One of benzodioxoles derivative, 4-(1,3-Benzodioxol-5-yl)-1-([1,10-biphenyl]4-ylmethylene) thiosemicarbazide was identified as a promising anticancer agent against glioma cells, C6 and lung adenocarcinoma cells, A549 due to its inhibitory effects on C6 and A549 cells and low toxicity to normal embryonic fibroblast cells, NIH/3T3 [13]. It caused a disturbance on the mitochondrial membrane potential and inhibited DNA synthesis in both A549 and C6 cells. Another benzodioxole derivative with a molecular structure of $\mathrm{CH} 2-\mathrm{C} 6 \mathrm{H} 4-\mathrm{O}-$ (2,6-di-Cl)-C6H also exhibited potent inhibitory effect on glioblastoma SF-295 cells, colon carcinoma HCT-8 cells, myeloblastic leukaemia $\mathrm{HL}-60$ cells and estrogen receptor-negative breast cancer MDA-MB435 cells due to its DNA-binding capacity in these cells [14]. Safrole (1, 3-benzodioxole, 5-(2-propenyl)), an analogue of dillapiole [15] was also cytotoxic to osteosarcoma, MG63 cells [16] and disrupted the morphology of leukaemia, HL-60 cells [17].

\subsection{Apoptosis Assay}

Figure 5 shows the results of Annexin V-FITC and propidium iodide staining assay to evaluate the apoptotic effects of dillapiole on RPMI 2650 cells. Based on Figure 5, scattered dispersion of representative results was shown in four quadrants that determine their potential to bind to specific dye. Q1 represents necrosis, Q2 indicates early apoptosis while Q3 serves live cells and Q4 expresses late 
apoptosis. For the untreated cells, the scattering was abundant in Q3 region where high dispersal was noted. Contrary with cisplatin treated cells, the smearing can be seen in Q2 and Q4 which proved that cisplatin has huge apoptotic effect. The cells that were treated with $\mathrm{IC}_{50} \mu \mathrm{M}$ dillapiole, the scattering is relatively distributed in parts of Q2 and Q4 regions whereby cells treated with $\mathrm{IC}_{75}$ dillapiole, shows that the smearing is highly seen in Q2 and Q4 regions. This finding also indicates that dillapiole induces RPMI 2650 cell death via induction of apoptosis, as there is an increase in the early and late apoptosis as observed.

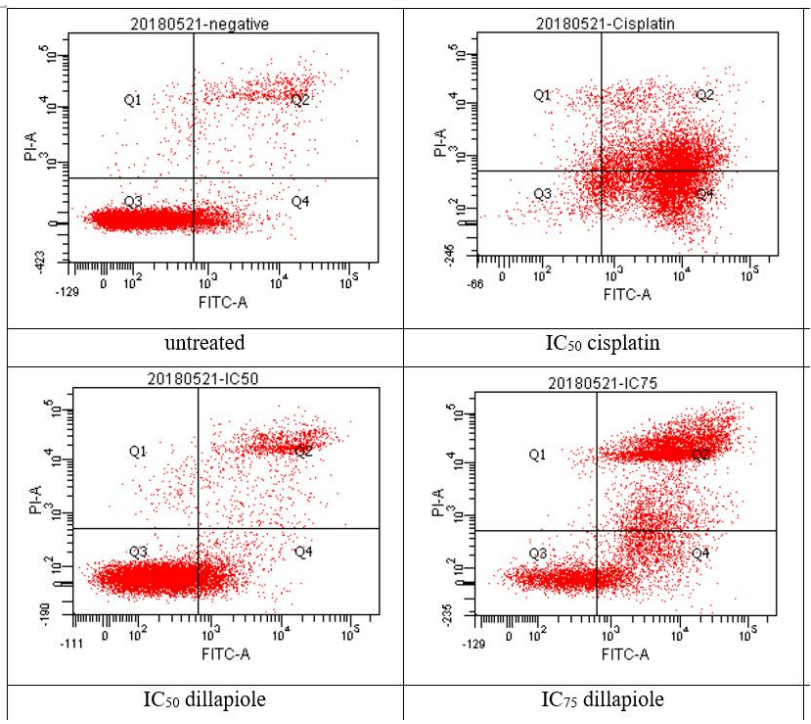

Figure 5 Scattered dispersion graph representative of Propidium iodide and Annexin V-FITC staining of RPMI 2650 human nasal squamous carcinoma cells after 72 hours treatment

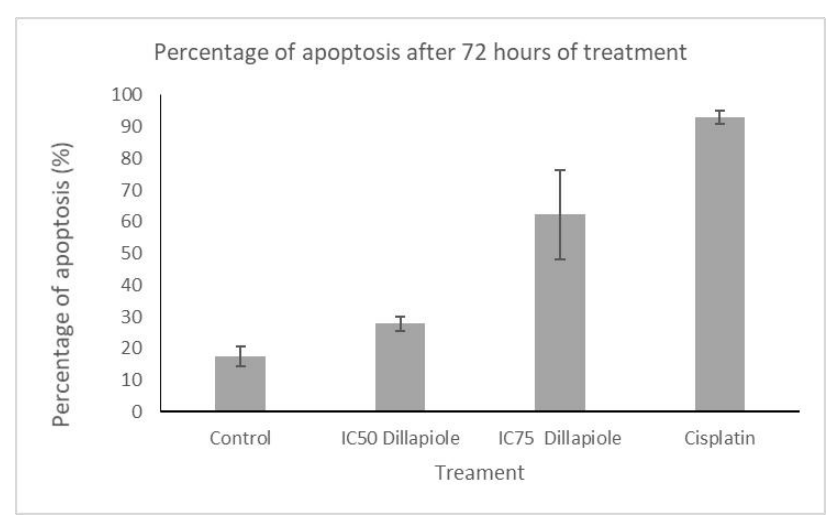

Figure 6 The percentage of apoptosis induced by dillapiole and cisplatin on RPMI 2650 cells

As shown in Figure 6, in RPMI 2650 cells, treatment with dillapiole resulted in $62.2 \%$ cell death compared to $92.84 \%$ treated with cisplatin that shows a high percentage of cell death, while in the control cells resulted to $17.63 \%$ of cell death.

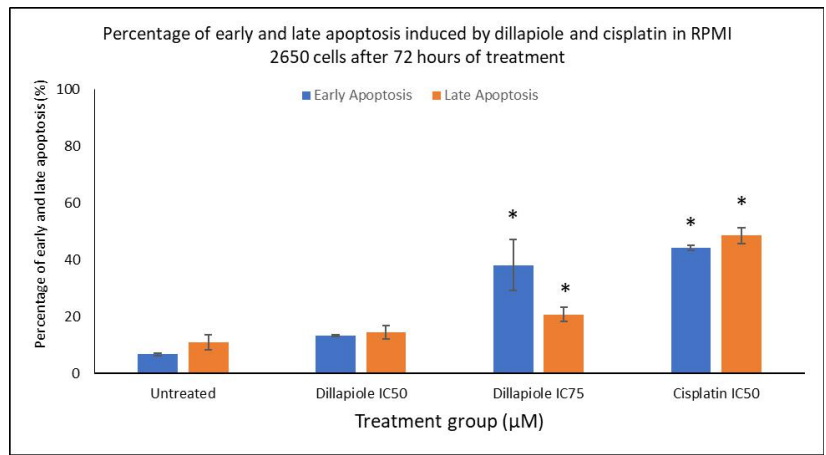

Figure 7 Effects of dillapiole and cisplatin on apoptosis in RPMI 2650 cells.

This graph was generated by calculating the cells residing in Q2 and Q4 regions obtained from all three sets of scatter plots represented in Figure 7. Dillapiole efficiently induced early apoptosis (Q2) by $13.02 \pm 0.25 \%(p<0.05, n=3)$ and late apoptosis (Q4) by $14.5 \pm 2.3 \%(p<0.05, n=3)$ in RPMI 2650 cells at $I C_{50}$ (46 $\mathrm{MM}$ ) concentration. Higher early and late apoptosis of $38.16 \pm 9.04 \%(p<0.05, n=3)$ and $20.7 \pm$ $2.5 \%(p<0.05, n=3)$, respectively was seen at $I_{75}(125$ $\mu \mathrm{M})$ concentration. Cisplatin induced $48.5 \pm 2.87 \%$ $(p<0.05, n=3)$ and $44.26 \pm 0.9 \%(p<0.05, n=3)$ of early and late apoptosis at $I \mathrm{C}_{50}$ concentration of $8 \mu \mathrm{M}$.

Defects in the apoptotic pathways can arise at any stage, resulting in malignant alteration of the cells, tumour spread, and can cause resistance in anticancer drugs. The process of apoptosis might be blocked in cancer cells. Induction of apoptosis was confirmed and observed via Annexin V-FITC/PI staining. Based on Figure 7 at similar $I_{50}$ of $46 \mu \mathrm{M}$ and $\mathrm{IC}_{75}$ of $125 \mu \mathrm{M}$, respectively minimal necrotic effect was obtained. Both dyes were able to detect and differentiate the morphological changes that occurred during the early and late stages of apoptosis, and necrotic cells. Previous study reported that at $50 \mu \mathrm{M}$, dillapiole induced apoptosis in MDAMB-231 cells via the mitochondrial dependent pathway caused by oxidative stress [11]. Other than that, dillapiole enhances the development of blastocysts to mature oocyte through the activation of apoptosis [18].

Similar to dillapiole, other phenylpropanoids such as asaricin and isoasarone (Piper sarmentosum Roxb extracts); and 1'S-1'-acetoxyeugenol acetate (Alpinia conchigera Griff extract) also induced apoptosis in MDA-MB-231 [19] breast cancer cells, while Sinkiangenone $B$ (Ferula sinkiangensis extract) induced apoptosis in gastric cancer, AGS cells [20]. Apart from that, the apoptotic effect of safrole, an analogue of dillapiole on various cancer cells has been well documented. Safrole induced apoptosis on oral cancer, HSC-3 cells [21] and leukaemia, HL-60 cells through the extrinsic and intrinsic signalling pathways, respectively [17]. Safrole oxide, induced 
apoptosis in lung cancer, A549 cells through activation of caspases family [22].

The ability of malignant cells to evade apoptosis is the hallmark of cancer. Understanding the basic element mechanisms of apoptosis might prevent the developing of cancer and resistance to chemo and radiotherapy [23] Morphologically, apoptotic cells death undergoes a series of changes that included membrane blebbing, chromatin condensation and DNA fragmentation [24]. Morphological hallmarks of apoptosis in the nucleus are chromatin condensation and nuclear fragmentation, which are accompanied by rounding up of the cell, reduction in cellular volume and retraction of pseudopods [23]. One of the main biochemical characteristics of apoptosis is the proteolytic activation of procaspases. Once activated into caspases, they triggered a series of event leading to the activate of other procaspases, thus amplifying the apoptotic signalling pathway and leading to the removal of damaged or unwanted cells without disrupting or damaging the surrounding cells and tissues [25]. Contrary to apoptosis, necrosis is an uncontrolled random and accidental cell death [9]. Cells that undergo necrosis are identified by the swelling of mitochondria and endoplasmic reticulum; and rupture of the plasma membrane that often resulted in inflammation to occur [26]. Dillapiole was reported to have antioxidant effect, thus enhanced its anti-proliferative effect on cancer cells as these cells were high in reactive oxygen species (ROS) compared to normal cells [15]. Antioxidant effect exerted from natural products were reported to contribute towards apoptotic effects instead on necrosis. It is well documented in many studies of natural compounds with anticancer and antioxidant properties have shown that their mode of action is through apoptosis induction $[27,28]$.

\subsection{CONCLUSION}

The reduction of the cell viability of RPMI 2650 cells suggest potent cytotoxic activity of dillapiole at dose dependent manner and the induction of apoptosis as the mechanism for cell death were observed.

Further understanding of the signaling transduction pathways both at gene and protein levels involving the regulation of vital key survival and apoptotic signaling mechanisms induced by dillapiole on human nasal epithelial carcinoma is required. These results could provide a baseline for in vivo study and enhanced the possibility for future clinical experiment settings.

\section{Acknowledgement}

This research is fully supported by the RAGS grant, RAGS/1/2015/SG0/UITM/02/3. The authors fully acknowledged the Ministry of Higher Education (MOHE) and Universiti Teknologi MARA for the approved fund and to the Faculty of Dentistry, UiTM for its valuable support which makes this important research viable and effective.

\section{References}

[1] Malik, S., Cusidó, R. M., Mirjalili, M. H., Moyano, E., Palazón, J., \& Bonfill, M. 2011. Production of the Anticancer Drug Taxol in Taxus Baccata Suspension Cultures: A Review. Process Biochemistry. 46(1): 23-34. DOI: http://dx.doi.org/10.1016/j.procbio.2010.09.004.

[2] Shah, U., Shah, R., Acharya, S., \& Acharya, N. 2013. Novel Anticancer Agents from Plant Sources. Chinese Journal of Natural Medicines. 11 (1): 16-23.

DOI: http://doi.org/10.1016/S1875-5364(13)60002-3.

[3] Khazir, J., Mir, B. A., Pilcher, L., \& Riley, D. L. 2014. Role of Plants in Anticancer Drug Discovery. Phytochemistry Letters. 7(1): 173-181.

DOI: http://doi.org/10.1016/j.phytol.2013.11.010.

[4] Mutee, A. F., Salhimi, S. M., Yam, M. F., Lim, C. P., Abdullah, G. Z., Ameer, O. Z., ... Asmawi, M. Z. 2010. In Vivo AntiInflammatory and In Vitro Antioxidant Activities of Peperomia Pellucida. International Journal of Pharmacology. 6(5): 686-690.

DOI: http://doi.org/10.3923/ijp.2010.686.690.

[5] Ooi, D. J., labal, S., \& Ismail, M. 2012. Proximate Composition, Nutritional Attributes, and Mineral Composition of Peperomia Pellucida L. (ketumpangan air) Grown in Malaysia. Molecules. 17(9): $11139-11145$. DOI: http://doi.org/10.3390/molecules170911139.

[6] Alves, N. S. F., Setzer, W. N., \& da Silva, J. K. R. 2019. The Chemistry and Biological Activities of Peperomia Pellucida (Piperaceae): A Critical Review. Journal of Ethnopharmacology. 232: 90-102. http://dx.doi.org/10.1016/j.jep.2018.12.021.

[7] de Lira, P. N. B., da Silva, J. K. R., Andrade, E. H. A., Sousa, P. J. C., Silva, N. N., \& Maia, J. G. S. 2009. Essential Oil Composition of Three Peperomia Species from the Amazon, Brazil. Natural Product Communications. 4(3): $1934578 \times 0900400323$.

DOI: http://dx.doi.org/10.1177/1934578X0900400323.

[8] Duprez, L., Wirawan, E., Berghe, T. Vanden, \& Vandenabeele, P. 2009. Major Cell Death Pathways at a Glance. Microbes and Infection. 11 (13): 1050-1062. DOI: http://doi.org/10.1016/j.micinf.2009.08.013.

[9] Ouyang, L., Shi, Z., Zhao, S., Wang, F. T., Zhou, T. T., Liu, B., \& Bao, J. K. 2012. Programmed Cell Death Pathways In Cancer: A Review of Apoptosis, Autophagy and Programmed Necrosis. Cell Proliferation. 45(6): 487-498. DOl: http://doi.org/10.1111/j.1365-2184.2012.00845.x.

[10] Chan, W. 2014. Cytotoxic Effects of Dillapiole on Embryonic Development of Mouse Blastocysts in Vitro and in Vivo. International Journal of Molecular Sciences. 15: 10751-10765.

DOI: http://doi.org/10.3390/ijms150610751.

[11] Kleber, A., Luiz, P., Fernanda, K., Pasqualoto, M. Alexandre, R., Azevedo, D., ... Parise, R. 2014. Cytotoxic Effects of Dillapiole on MDA-MB-231 Cells Involve the Induction of Apoptosis through the Mitochondrial Pathway by Inducing an Oxidative Stress While Altering the Cytoskeleton Network. Biochimie. 99: 195-207. DOI: http://doi.org/10.1016/j.biochi.2013.12.008.

[12] Almeida, V. G., Pinto, M. C. X., \& Moura, F. A. G. 2014. Trypan Blue Exclusion Assay By Flow Cytometry. Brazilian Journal of Medical and Biological Research. 47(4): 307-315. DOI: $\quad$ http://doi.org/http://dx.doi.org/10.1590/1414$431 \times 20143437$.

[13] Altintop, M. D., Temel, H. E., Sever, B., Çiftçi, G. A., \& Kaplancikli, Z. A. 2016. Synthesis and Evaluation of New Benzodioxole-based Thiosemicarbazone Derivatives as Potential Antitumor Agents. Molecules. 21 (11): 1-18. DOI: https://doi.org/10.3390/molecules21111598. 
[14] Moreira, D. R. de M., Lima Leite, A. C., Pinheiro Ferreira, P. M., da Costa, P. M., Costa Lotufo, L. V., de Moraes, M. O., ... do Ó Pessoa, C. 2007. Synthesis and Antitumour Evaluation of Peptidyl-Like Derivatives Containing the 1,3Benzodioxole System. European Journal of Medicinal Chemistry. 42(3): 351-357. DOI: https://doi.org/10.1016/j.ejmech.2006.10.007.

[15] Parise-filho, R., Pastrello, M., Emygdio, C., Camerlingo, P. Silva, G. J., Agostinho, L. A., ... Polli, M. C. 2011. The AntiInflammatory Activity of Dillapiole and Some Semisynthetic Analogues. Pharmaceutical Biology. 49(11): 1173-1179.

DOI: https://doi.org/10.3109/13880209.2011.575793.

[16] Lin, H. C., Cheng, H. H., Huang, C. J., Chen, W. C., Chen, I. S., Liu, S. I., ... Jan, C. R. 2006. Safrole-Induced Cellular $\mathrm{Ca} 2+$ Increases and Death in Human Osteosarcoma Cells. Pharmacological Research. 54(2): 103-110. DOI: https://doi.org/10.1016/j.phrs.2006.03.002

[17] Yu, C. S., Huang, A. C., Yang, J. S., Yu, C. C., Lin, C. C., Chung, H. K., ... \& Chung, J. G. 2012. Safrole Induces G0/G1 Phase Arrest Via Inhibition of Cyclin E and Provokes Apoptosis Through Endoplasmic Reticulum Stress and Mitochondrion-Dependent Pathways in Human Leukemia HL-60 cells. Anticancer Researcher. 32(5): 1671-1679.

[18] Hsuuw, Y. Der, \& Chan, W. H. 2015. Apoptotic Effects Of Dillapiole on Maturation of Mouse Oocytes, Fertilization and Fetal Development. Drug and Chemical Toxicology. 38(4): 469-476. DOl: https://doi.org/10.3109/01480545.2014.1002037.

[19] Hematpoor, A., Paydar, M., Liew, S. Y., Sivasothy, Y., Mohebali, N., Looi, C. Y., ... Awang, K. 2018. Phenylpropanoids Isolated from Piper Sarmentosum Roxb. Induce Apoptosis in Breast Cancer Cells Through Reactive Oxygen Species and Mitochondrial-Dependent Pathways. Chemico-Biological Interactions. 279: 210-218. https://doi.org/10.1016/j.cbi.2017.11.014.

[20] Wang, J., Gao, Y., Wang, H., Chen, L., Cao, L., Xu, J., ... Si, J. 2018. Apoptosis Induction and Cell Cycle Arrest Induced By Sinkiangenone B, A Novel Phenylpropanoid Derivative from the Resin of: Ferula Sinkiangensis K. M. Shen. Royal Society of Chemistry Advances. 8(8): 4093-4103.
DOI: https://doi.org/10.1039/c7ral3716h.

[21] YU, F.-S., Yang, J.-S., YU, C.-S., LU, C.-C., Chiang, J.-H., Lin, C.-W., \& Chung, J.-G. 2011. Safrole Induces Apoptosis In Human Oral Cancer HSC-3 Cells. Journal of Dental Research. 90(2): 168-174. DOI: https://doi.org/10.1177/0022034510384619.

[22] Du, A., Zhao, B., Miao, J., Yin, D., \& Zhang, S. (2006). Safrole Oxide Induces Apoptosis by Up-regulating Fas and Fasl Instead of Integrin B4 in A549 Human Lung Cancer Cells. Bioorganic and Medicinal Chemistry, 14(7): 2438-2445. DOI: https://doi.org/10.1016/j.bmc.2005.11.026.

[23] Wong, R. S. 2011. Apoptosis In Cancer: From Pathogenesis to Treatment. Journal of Experimental and Clinical Cancer Research. 30(1): 87. DOI: https://doi.org/10.1 186/1756-9966-30-87

[24] Dang, T. P. 2012. Notch, Apoptosis and Cancer. Notch Signaling in Embryology and Cancer. 199-209. DOI: http://dx.doi.org/10.1007/978-1-4614-0899-4 15.

[25] Kasibhatla, S., \& Tseng, B. 2003. Why Target Apoptosis in Cancer Treatment? Molecular Cancer Therapeutics. 2(6): 573-580.

[26] Nikoletopoulou, V., Markaki, M., Palikaras, K., \& Tavernarakis, N. 2013. Crosstalk Between Apoptosis, Necrosis and Autophagy. Biochimica et Biophysica Acta Molecular Cell Research. 1833(12): 3448-3459. https://doi.org/10.1016/j.bbamcr.2013.06.001.

[27] Carullo, G. Mazzotta, S. Koch, A., Hartmann, K. M. Friedrich, O., Gilbert, D. F., ... \& Aiello, F. 2020. New Oleoyl Hybrids of Natural Antioxidants: Synthesis and In Vitro Evaluation as Inducers of Apoptosis in Colorectal Cancer Cells. Antioxidants. 9(11): 1077. https://doi.org/10.3390/antiox9111077.

[28] Luangpraditkun, K., Tissot, M., Joompang, A., Charoensit P., Grandmottet, F., Viyoch, J., \& Viennet, C. 2021. Prevention by the Natural Artocarpin of Morphological and Biochemical Alterations on UVB-Induced HaCaT Cells. Oxidative Medicine and Cellular Longevity. 2021. https://doi.org/10.1155/2021/5067957 